\title{
Brown bear Ursus arctos predation on livestock in the Cantabrian Mountains, Spain
}

\author{
Anthony P. CLEVENGER*, Miguel Angel CAMPOS \\ and Alfonso HARTASANCHEZ
}

\begin{abstract}
Clevenger A. P., Campos M. A. and Hartasanchez A. 1994. Brown bear Ursus arctos predation on livestock in the Cantabrian Mountains, Spain. Acta theriol. 39: 267-278.

The sites of 87 brown bear Ursus arctos Linnaeus, 1758 attacks on livestock (horses, cattle, sheep, goats) were investigated in the Cantabrian Mountains, Spain. Ninety percent of livestock predation occurred between May and October, while attacks were most frequent during the months of May and July. There was no difference in overall attack rates between the first and second part of the year, nor among livestock type or age-class. Bears were not selective predators of livestock type or age-class, but had a slight tendency to attack more cattle and adult animals. Bear tracks and scats were found at slightly more than half of the sites visited, while bed construction and food-caching behaviour was rarely detected. Attacks were initiated most times on the neck and the head region. Muscle tissue and soft organs were most preferred body parts consumed by brown bears.
\end{abstract}

Department of Forestry, Wildlife \& Fisheries, University of Tennessee, Knoxville, TN 37901 USA and Departamento de Biología Animal, Universidad de León, E-24071 León, Spain (APC); Consultora de Recursos Naturales, c/Pintorería 68, ofic. 2, E-01001 Vitoria, Spain (MAC); FAPAS, Apdo. 106, Poo de Llanes (Asturias), Spain (AH)

Key words: Ursus arctos, livestock predation, Cantabrian Mountains, Spain

\section{Introduction}

Brown bear Ursus arctos Linnaeus, 1758 attacks on livestock have been occurring for centuries and form a part of the folklore in many mountain regions of Europe (Couturier 1954, Notario 1970). Historically, destructive animals were poisoned, trapped or shot in attempts to reduce the number of losses incurred to domestic animals and farm crops. As a result, today they have become extinct in most of western Europe (Sorensen 1990), and their remaining populations are small and fragmented (Servheen 1989).

In southern Europe, four relict brown bear populations continue to survive; including one located in northern Spain's Cantabrian Mountains (Clevenger et al. 1987). The most recent population estimates indicated that approximately $60-70$

\footnotetext{
* Present address: U. S. Forest Service, Pacific Southwest Experiment Station, Redwood Sciences Laboratory, 1700 Bayview Drive, Arcata, CA 95521, USA
} 
brown bears remain in the Cantabrian Mountains (Clevenger and Purroy 1991b). The two nuclei are disparate in size as the western nucleus accounts for more than two-thirds of the population. Wolves Canis lupus Linnaeus, 1758, are more abundant than bears in the Cantabrian Mountains; however, there are no population estimates for the mountain region or the brown bears' range.

Cantabrian bears were reported to be efficient scavengers of wild and domestic ungulates (Clevenger et al. 1992). Livestock densities are high and provide bears a steady supply of carrion throughout the year. Although bear predation on livestock was infrequent (Purroy et al. 1988), livestock formed a relatively important part of the bears diet (Clevenger et al. 1992).

Only within the last two decades the regional governments in the Cantabrian Mountains have provided monetary compensation to livestock owners incurring losses from brown bear attacks. However, before payments can be made, bear kills must be correctly identified.

In other European brown bear populations, livestock damages have been quantified (Camarra 1986, Clevenger and Purroy 1991a) and their attacks and feeding behaviour described (Mysterud 1975, 1980). Nonetheless, there still is a lack of basic information on the characteristics of brown bear attacks on livestock, especially in southern Europe. Consequently, many wildlife managers responsible for brown bear management are faced with the problem of identifying bear-killed livestock from other potential predators or fabricated simulations. Greater confidence in determining bear livestock predation will only come from increased information on their characteristics.

The sites of brown bear attacks on livestock were visited in the Cantabrian Mountains during a 7-year period. In this paper we summarize the information and describe the attack characteristics and brown bear feeding behaviour, and compare it to what has been reported from other populations, primarily those from Europe.

\section{Study area}

The Cantabrian Mountains are situated on an east-west axis parallel and adjacent to the Cantabrian Sea in northern Spain $\left(42^{\circ} 50^{\prime}-43^{\circ} 10^{\prime} \mathrm{N}, 4^{\circ} 20^{\prime}-6^{\circ} 55^{\prime} \mathrm{W}\right)$. They extend for $300 \mathrm{~km}$ across portions of the provinces of Asturias, Cantabria, Leon, Palencia and Lugo and occupy an area of ca $18,000 \mathrm{~km}^{2}$. The Cantabrian brown bear range encompasses roughly $5000 \mathrm{~km}^{2}$ and is composed of two isolated groups (Fig. 1; Clevenger et al. 1987). The eastern and western nuclei are of equal area and separated by approximately $50 \mathrm{~km}$. Nearly all of the bear range is located within seven contiguous National Hunting Reserves (NHR) governed by four Autonomous Communities (Asturias, Cantabria, Castile-León, and Galicia).

Elevations range from $600 \mathrm{~m}$ to $2500 \mathrm{~m}$, although the mean altitude along the divide is $1200-1600$ $\mathrm{m}$. The north and south sides of the range differ in physiography and climate as they separate the Eurosiberian and Mediterranean biogeographic regions (Rivas-Martinez et al. 1984). South side climate (León, Lugo, Palencia provinces) is continental and mean monthly temperatures range from $0.5^{\circ} \mathrm{C}$ to $16^{\circ} \mathrm{C}$. Maritime conditions prevail on the north side (Asturias and Cantabria) as monthly mean temperatures range from $5^{\circ} \mathrm{C}$ to $17^{\circ} \mathrm{C}$. 


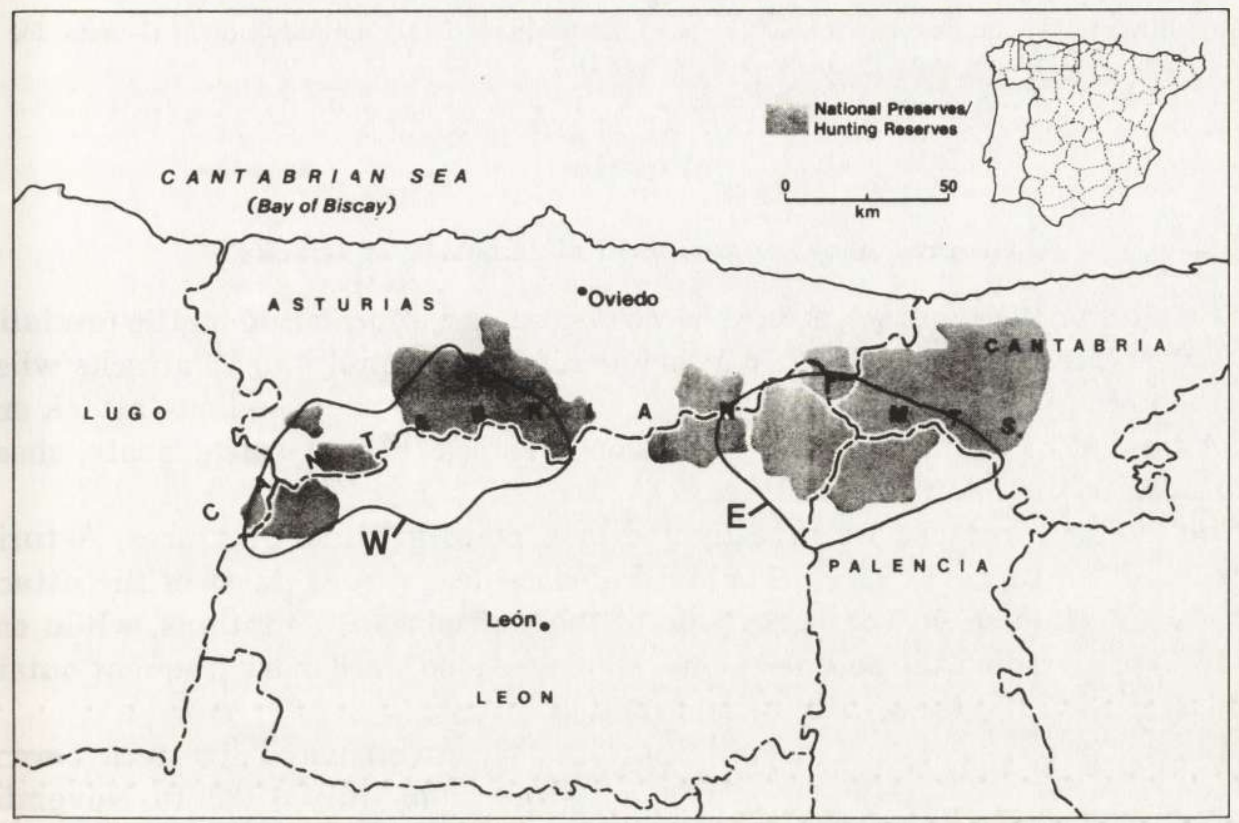

Fig. 1. Map of the Cantabrian brown bear range, including eastern (E) and western (W) nuclei.

Vegetation in the bear range consists of three broad communities: shrublands (Genista, Cytisus, Erica and Calluna spp.) are common at middle and low elevations where grazing pressure and periodic burnings have declined; grazing lands at high elevations and maintained lowland pastures; and mixed-deciduous forests predominantly of beech Fagus sylvatica and oak Quercus spp.

Wolves are the only large predator coexisting with brown bears. Free-ranging or feral dogs are not common in the Cantabrian Mountains.

The main economic activity of the region is livestock production, primarily cattle. From April to November, resident herds utilize the abundant grazing lands and pastures throughout the mountains, but increase in number during summer when migratory sheep arrive from the south.

\section{Methods}

We investigated the sites of livestock attacks in the Cantabrian Mountains that were reported to be caused by brown bears. At the carcass area, we recorded the type of livestock attacked (horse, cattle, goat, sheep) and its age (yearling or adult). The estimated time since the attack occurred was based on the state of decay of the carcass and condition of sign in the area. We noted the parts of the body where feeding took place, and when fresh carcasses were examined, we determined the method of attack, i.e. the location on the body where the attack initiated. Within a $25-30 \mathrm{~m}$ radius of the carcass area, we recorded the presence or absence of bears scats, tracks, and beds, and if the bear dragged or buried the carcass.

For some analyses, we were interested in investigating seasonal differences in the bears' predatory behaviour. Time of year when attacks occurred were divided into two seasons: spring-early summer (15 March to 31 July) and late summer-autumn (1 August to 15 December). These months were selected because bears are normally inactive from December to March (Clevenger and Purroy 
1991a). Statistical significance $(p<0.05)$ was determined using nonparametric $G$-tests for all comparisons of frequency data (Sokal and Rohlf 1981).

\section{Results}

\section{Geographical and temporal distribution of attacks}

The sites of 101 livestock attacks were visited and information on the predation characteristics were quantified. We excluded from the analysis, 13 attacks where it was uncertain whether they were caused by a brown bear, and one attack on a pig. A total of 87 confirmed bear attacks on livestock (horses, cattle, goats, sheep) were used in the following analyses.

The livestock attacks we investigated took place in three provinces; Asturias ( $84 \%, n=73)$, León ( $13 \%, n=11)$ and Palencia ( $3 \%, n=3)$. Most of the attacks (84\%) were situated on the north side of the Cantabrian Mountains, while only $14(16 \%)$ occurred on the southern side. Damages also were more frequent outside of the NHR's (74\%) than within them $(26 \%)$.

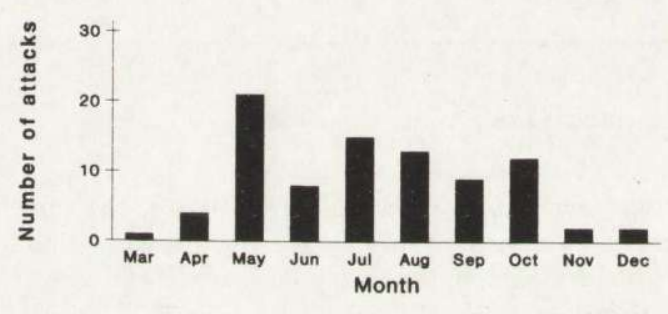

Fig. 2. Monthly distribution of brown bear attacks on livestock in the Cantabrian Mountains, 1983-1991.
We investigated livestock carcass sites from July 1983 to November 1991 , however $78 \%$ of the visits occurred during 1985 and 1986. Bear predation on livestock was most frequent during the month of May (24\% of all attacks), followed by July (17\%) and August (15\%) (Fig. 2). Ninety percent ( $n=68$ attacks) of the livestock damages occurred between May and October.

\section{Livestock predation chronology}

There was no significant difference between the number of bear attacks on livestock during the spring-early summer season (56\% of attacks) and late summer-autumn ( $44 \%)(G=1.4, p=0.2$; Table 1). A significant difference between the expected predation among the four livestock types and the observed frequency of kills occurred during the first season $(G=11.4, p=0.02)$, however, not in the second part of the year $(G=1.0, p=0.8)$. Between seasons brown bears preyed upon livestock types differently $(G=20.6, p<0.001)$. Cattle and goats were attacked more often during the first half of the year than the latter (both $p<$ $0.001)$, while the contrary was observed for sheep $(p<0.005)$.

During the first half of the year, bears did not manifest any age selection in the livestock they attacked $(G=0.02, p=0.87)$, whereas in the second term bears attacked a significantly greater number of adults than yearlings $(G=7.8$, 
Table 1. Number and percentage (\%) of brown bear attacks on livestock types and age-classes by season occurring in the Cantabrian Mountains, 1983-1991. * Significant differences between seasons $(p<0.01)$.

\begin{tabular}{|c|c|c|c|}
\hline \multirow{2}{*}{$\begin{array}{l}\text { Livestock type } \\
\text { and age }\end{array}$} & \multicolumn{2}{|c|}{ Season } & \multirow{2}{*}{ Total } \\
\hline & Mar 15-Jul 31 & Aug 1-Dec 15 & \\
\hline Horses & 11 & 7 & 18 (21) \\
\hline adult & 3 & 4 & 7 \\
\hline yearling & 8 & 2 & 10 \\
\hline undetermined & 0 & 1 & 1 \\
\hline Cattle & $19 *$ & 11 & 30 \\
\hline adult & 9 & 4 & 15 \\
\hline yearling & 10 & 6 & 14 \\
\hline undetermined & 0 & 1 & 1 \\
\hline Goats & $15^{*}$ & 10 & $25 \quad(29)$ \\
\hline adult & 8 & 10 & 18 \\
\hline yearling & 7 & 0 & 7 \\
\hline Sheep & $4^{*}$ & 10 & 14 (16) \\
\hline adult & 4 & 8 & 12 \\
\hline yearling & 0 & 2 & 2 \\
\hline Total & $49(56)$ & $38(44)$ & $87(100)$ \\
\hline adult & 24 & 28 & $52(60)$ \\
\hline yearling & 25 & 8 & 33 \\
\hline undetermined & 0 & 2 & $2 \quad(2)$ \\
\hline
\end{tabular}

$p=0.008$ ). There was no significant difference in the number of attacks on adult and yearling animals of each livestock type during the first season (all $p>0.10$ ). However, in the second season, a significantly greater number of adult goats were attacked compared to yearlings $(G=6.93, p=0.005)$, while predation on the other domestic animals was not age-selective (all $p>0.10$ ).

\section{Type- and age-specific predation}

Of the 87 bear kills documented, there was no significant difference in predation among the livestock types $(G=7.1, p=0.07)$. Cattle constituted $34 \%(n=30)$ of the attacks, followed by goats $(29 \%)$ and horses $(21 \%)$; predation on sheep was least frequent, occurring on $14(16 \%)$ occasions.

Bears exhibited age-selection in attacks on the four types of livestock, although it was slight $(G=4.3, p=0.04)$. Bears attacked adult animals on $52(60 \%)$ occasions, yearling animals $33(38 \%)$ times, and on two instances age could not be determined. However, bears preyed upon adult sheep more than yearlings $(G=7.9, p=0.02)$, while no differences were observed among the other types (all $p>0.10$ ). 


\section{Carcass site characteristics}

Bear tracks were found at $63 \%$ of the carcass sites, but overall there was no significant difference of track presence among the four livestock types $(G=5.8$, $p=0.12$ ) (Table 2). Similarly, brown bear scats were encountered at $61 \%$ of the carcass sites, and their presence among the types of livestock attacked vas not significant $(G=3.8, p=0.28)$.

Bears were more likely to not construct beds at the carcass sites as they were absent at $84 \%$ of the bear kills. The absence of beds at carcass sites was significantly different among all livestock types $(G=40.1, p<0.001)$. At the attack sites of horses, cattle and sheep, the occurrence of beds was less than expected by chance (all $p<0.01$ ), while beds were more frequently found at goat carcasses.

Table 2. Summary statistics for site characters recorded at carcass sites in the Cantabrian Mountains, Spain, 1983-1991. In parentheses are number of sites missing data. ${ }^{*}-p<C .01$, $* *-p<0.001$.

\begin{tabular}{|c|c|c|c|c|c|}
\hline \multirow{2}{*}{$\begin{array}{l}\text { Carcass site } \\
\text { characters }\end{array}$} & \multicolumn{4}{|c|}{ Livestock type } & \multirow{2}{*}{ Total } \\
\hline & Horses & Cattle & Goats & Sheep & \\
\hline \multicolumn{6}{|l|}{ Tracks } \\
\hline Present-absent & $14-4$ & $14-9 \quad(7)$ & $14-9$ & $7-6 \quad(1)$ & $49-28 \quad(10)$ \\
\hline \multicolumn{6}{|l|}{ Scats } \\
\hline Present-absent & $13-5$ & $12-11 \quad(7)$ & 14-9 (2) & $8-5 \quad(1)$ & $47-30 \quad(10)$ \\
\hline \multicolumn{6}{|l|}{ Beds } \\
\hline Present-absent & $1-17^{*}$ & $3-20 *(7)$ & $8-15$ & $0-13^{*}(1)$ & $12-65^{* *}(10)$ \\
\hline \multicolumn{6}{|l|}{ Carcass dragged } \\
\hline Yes-no & $6-10(2)$ & $12-6 \quad(12)$ & $5-17$ & 6-7 (1) & $29-40 \quad(18)$ \\
\hline \multicolumn{6}{|l|}{ Carcass buried } \\
\hline Yes-no & $3-14 *(1)$ & $0-18^{*}(12)$ & $4-19 *(2)$ & 4-7 (3) & $11-58^{* *}(18)$ \\
\hline
\end{tabular}

Among the livestock carcasses examined, there was no clear tendency to drag them from the kill site. Bears did not drag carcasses on 40 (58\%) occasions, while on $29(42 \%)$ occasions they did. There was no significant difference in carcass-moving by bears at the kill site among the four livestock types $(G=1.7, p=0.2)$, however, only cattle were dragged more times than not.

There was a tendency by brown bears to not bury or cover livestock carcasses after killing them. On 58 ( $84 \%)$ occasions bears left carcasses uncovered, while on only $11(16 \%)$ sites did bears bury their kill. At the carcass sites of horses, cattle, and goats, bears showed a tendency to not bury their carcasses (all $p<0.01$ ), whereas no pattern was detected at sheep carcasses. 


\section{Bear killing and feeding behaviour}

Only 21 fresh carcasses were examined that enabled us to determine the location on the body where the attack occurred. These included carcasses from 12 cattle, 8 horses, and 1 ewe (Table 3 ).

The 12 cattle carcasses consisted of 10 cows and 2 calves. Cows bore bite wounds on the neck in seven cases, and once on the shoulder, hind quarters, and udder. Calves were attacked once on the neck and back region; in the latter the calf appeared to receive a strong blow by the bear. On three of the twelve attacks, claw marks were found on the hind quarters, most likely indicating a struggle occurred prior to the killing. More evidence of a fight or struggle might have been documented but most carcasses hind quarters were eaten.

Table 3. Location on body where livestock were attacked by brown bears in the Cantabrian Mountains, 1983-1991.

\begin{tabular}{lcccc}
\hline \multirow{2}{*}{ Body part } & \multicolumn{3}{c}{ Livestock type } & \multirow{2}{*}{ Total } \\
\cline { 2 - 4 } & Horses & Cattle & Sheep & \\
\hline Head & 3 & 0 & 0 & 3 \\
Neck & 3 & 8 & 0 & 11 \\
Shoulder & 0 & 1 & 0 & 1 \\
Vertebral column & 0 & 1 & 1 & 2 \\
Hind quarter & 1 & 1 & 0 & 2 \\
Flank & 1 & 0 & 0 & 1 \\
Udder & 0 & 1 & 0 & 1 \\
Total & 8 & 12 & 1 & 21 \\
\hline
\end{tabular}

Table 4. Location on body of livestock where brown bear feeding took place after attacks, Cantabrian Mountains, 1983-1991.

\begin{tabular}{lccccr}
\hline \multirow{2}{*}{ Body part } & \multicolumn{4}{c}{ Livestock type } & \multirow{2}{*}{ Total } \\
\cline { 2 - 4 } & Horses & Cattle & Goats & Sheep & \\
\hline Head & 2 & 0 & 0 & 0 & 2 \\
Neck & 3 & 7 & 0 & 0 & 10 \\
Shoulder & 0 & 3 & 0 & 0 & 3 \\
Breast \& front quarter & 3 & 6 & 0 & 0 & 9 \\
Rump \& hind quarter & 4 & 9 & 0 & 1 & 14 \\
Flank & 0 & 1 & 0 & 0 & 1 \\
Viscera & 5 & 7 & 0 & 1 & 13 \\
土100\% consumed & 7 & 1 & 2 & 0 & 10 \\
Total & 24 & 34 & 2 & 2 & 62 \\
\hline
\end{tabular}


Of the 8 horses examined, 3 were mares and 5 were yearlings. Attacks on mares were directed one time each at the neck, hind quarters, and flank. Yearlings, however, were attacked by the head on 3 of the 5 occasions; two being directed at the nasal region and one on the cranium. Two yearlings also were attacked on the neck. Struggles between bear and horses could not be identified because a substantial part of most of the carcasses were consumed prior to our arrival. On one occasion, the nearly-born fetus of an attacked mare was removed from her womb but left uneaten. The only instance where we could identify the method a bear used to kill a ewe was that of a blow to the vertebral column.

Data regarding the parts of the body consumed by bears after attacks were collected from 62 of the 87 carcasses examined (Table 4). These included carcasses from 34 cattle, 24 horses, 2 goats, and 2 sheep.

The most commonly consumed part of cattle was the hind quarter $(26 \%$ of carcasses), followed by the neck and viscera (21\%), and breast-front quarter (18\%). Among horses, 7 of the 24 carcasses (29\%) were nearly devoured, while the viscera was eaten at $5(21 \%)$, and the hind quarter at $4(17 \%)$. Goats were entirely consumed, whereas on 2 sheep, the hind quarter and viscera were eaten.

\section{Discussion}

This paper presents the first information on the predation characteristics of brown bears feeding on more than one type of livestock. Despite its qualitative nature, it nonetheless demonstrates some noteworthy feeding patterns occurring among one population in the southern part of the species range. Documentation on European brown bear-livestock relationships has been limited, and most published articles describe the bears' interactions with one prey-type (generally sheep). Furthermore, most reports are from Scandinavia and Central Europe, while those from southern Europe are rare.

Bear attacks on livestock we have described in this paper were most frequent in the province of Asturias, the north side of the Cantabrian divide, and also predominantly occurred outside of the NHR's. Not all livestock damages during the study period were investigated. However, the geographical sampling of attacks reported reflect our bias towards the province of Asturias, and the north side of the range, where nearly all livestock attacks were reported to one of the authors (AH). Why more bear attacks occurred outside of the NHR's cannot be explained by greater bear abundance or livestock density in the unprotected areas, but may be an artifact of several problem-bears or relaxed herding practices.

Bear predation on wild and domestic ungulates often is highest in spring and late autumn, when physiological demands are greatest (Haglund 1968). In the Cantabrian Mountains, however, most livestock predation took place in summer, and more than $90 \%$ of the attacks occurred from May to October, which coincides when livestock were most abundant in the mountains. Previous results from a 
portion of the Cantabrian bear range (Riaño NHR) showed a similar trend as two peaks in bear attack frequencies occurred during the year; in May and September-October (Clevenger and Purroy 1988). Camarra (1986) also found that the number of Pyrenean bear attacks on livestock was greatest when the latter were most abundant in the bears' range. In this paper we did not quantify predation rates with livestock abundance, however, there did not appear to be a correlation between the two variables in our study area.

Overall, bears did not exhibit age-selective predation, nor preference for any of the four livestock types occurring in the mountains. Cattle and goats were most frequently killed, and horses and sheep less so. In the Riaño NHR, on the south side of the range, sheep and goats were preyed upon most, while few attacks on cattle and horses occurred (Clevenger and Purroy 1988). Bear predation rates on livestock reported herein, and those of Clevenger and Purroy (1988), are in accordance with the relative abundance of livestock types available in each study area (Purroy et al. 1988).

Mysterud (1975) noted that bears may engage in many activities around carcass sites and leave sign such as tooth marks, claw marks, resting beds, scats, scraping and covering of carcasses, twisted and broken live trees, branch plucking, and ant nest destruction. In our study, tracks and scats were just as likely to be absent from carcass sites as they were present, as no clear pattern was observed. Moose Alces alces and sheep carcass site descriptions from Scandinavia reported the presence of scats at nearly all sites, however, their sample sizes were small and may not demonstrate a true pattern (Mysterud 1973, 1975, Elgmork 1982).

The use of resting beds in carcass areas is a regular habit among Scandinavian brown bears after killing moose or sheep, as bears may spend several days feeding on a single carcass (Mysterud 1973, 1975, Elgmork 1982). Throughout their holarctic range, brown bears also have exhibited food-caching behaviour (Haglund 1968, Craighead and Craighead 1972, Semenov-Tian-Shanskii 1972, Mysterud 1973, 1975, Elgmork 1982). Carcass burying has been interpreted to reduce interspecific and intraspecific competition due to elimination of scent, however, few data are available on carcass competition among bears and their conspecifics (Mysterud 1975). An interesting result was that we found that Cantabrian bears showed a strong tendency to not construct beds at their kill sites. Beds were rarely encountered at horse, cattle and sheep kills, and were only found with a certain regularity at goat carcass sites.

The carcass site characteristics of Cantabrian bear predation on livestock suggested that, no matter the type or size of animal killed, bears rarely exhibited food-caching behaviour and were not likely to remain in the area for any extended period of time. Bears may return daily to feed upon their carcasses, however, the apparent absence of beds at the kill-site indicated that they did not remain in the vicinity of their prey. The scarcity of scats found at the carcass sites also lends support that Cantabrian bears may be spending less time at kill-sites than Scandinavian brown bears. 
Why Cantabrian bears do not remain within the vicinity of their livestock kills like Scandinavian bears, might be explained by long-standing differences in human density and amount of activity where bears live in the two extremes of their European distribution. The Cantabrian bear range can be characterized by its relatively high human population and intense agro-pastoral activity compared to Scandinavian bear habitat. We speculate that Cantabrian bears coexistence with humans during the last 2-3 centuries may have conditioned them so that repeated visits to or permanence at carcass sites might make them more vulnerable to human predation.

Data on the bears' killing and feeding behaviour were not as numerous as we had hoped for, however, some patterns could be seen from the cases investigated. Cattle and mares killed by bears most times bore bite wounds on the neck, whereas attacks on yearling horses were generally focused on the head. These findings are similar to those reported elsewhere. Murie (1948) determined that bites on the neck were the wound generally found on cattle killed by grizzly bears, while Mysterud (1975) reported that the most common feature on domestic sheep killed by brown bears in Norway were canine tooth punctures of the forehead and nasal region. In southeastern Idaho (USA), Griffel and Basile (1981) also reported that sheep killed by bears had puncture wounds in the nape and skull.

In the cases cited above, all concluded that deaths were caused by bite wounds. Mysterud (1975) hypothesized that deep bite wounds in the facial and nasal region induced shock and paralysis, while Murie (1948) speculated that wounds to the lumbar and neck region caused temporary paralysis. Striking blows by bears have generally been discounted by most authors as a means of killing wild or domestic ungulates, however, nearly all agree that they may be used prior to administering a killing bite (Murie 1948, Mysterud 1975) or begin feeding (French and French 1990). Although bite and strike wounds were observed on livestock killed by bears in our study area, we suspect that most attacks were initiated on the head and neck region, as our data suggests. Whether attacked animals died from these initial wounds or by other means is unknown.

For Cantabrian bears the hind-quarters and viscera of cattle were preferred, while among horses the latter was eaten most. Preference for soft organs from the visceral region (liver, heart, lungs, udder, etc.) is commonly reported from Scandinavian and North American bear populations (Murie 1948, Mysterud 1975, French and French 1990). Noteworthy was the apparent preference of Cantabrian bears for muscle tissue, in the form of hind- and fore-quarters. Although carcass meat is reportedly disdained by most predating ursids, Couturier (1954) described similar feeding behaviour among Pyrenean bears.

Characteristics of kills reported in this paper indicate that Cantabrian bears were opportunistic predators of livestock. Bear predation was not selective of livestock type or age, but was greatest when livestock were most abundant. Presence of tracks and scats at carcass appear to be fairly reliable indicators of bear predation, whereas bed construction and food-caching were rarely observed. 
Attacks were initiated most times on the neck and head region, however, additional data are needed to better define bear killing and feeding behaviour. To provide greater accuracy in identifying bear-killed livestock, we suggest that more work should be carried out, including detailed studies on wolf predation characteristics. These will serve to better differentiate the predation characteristics of the two carnivores in this part of their range.

\section{References}

Camarra J.-J. 1986. Changes in brown bear predation on livestock in the western French Pyrenees from 1968 to 1979. Int. Conf. Bear Res. and Manage. 6: 183-186.

Clevenger A. P. and Purroy F. J. 1988. El oso en León. Serv. Publs. Universidad de León, León: 1-127.

Clevenger A. P. and Purroy F. J. 1991a. Ecología del oso pardo en España. Mus. Nac. de Ciencias Nat., Monogr. No. 4: 1-155. [In Spanish with English summary]

Clevenger A. P. and Purroy F. J. 1991b. Demografía del oso pardo en la Cordillera Cantábrica. Ecología 5: 243-256. [In Spanish with English summary]

Clevenger A. P., Purroy F. J. and Pelton M. R. 1992. Food habits of brown bears (Ursus arctos) in the Cantabrian Mountains, Spain. J. Mammal. 73: 415-421.

Clevenger A. P., Purroy F. J. and Sáenz de Buruaga M. 1987. The status of the brown bear in the Cantabrian Mountains, Spain. Int. Conf. Bear Res. and Manage. 7: 1-8.

Couturier M. 1954. L'ours brun. M. Couturier, Grenoble: 1-749.

Craighead F. C. and Craighead J. J. 1972. Data on grizzly bear denning activities and behaviour obtained by using wildlife telemetry. [In: Bears - their biology and management. S. Herrero, ed]. IUCN Publ. new Ser. 23: 84-106.

Elgmork K. 1982. Caching behavior of brown bears (Ursus arctos). J. Mammal. 63: 607-612.

French S. P. and French M. G. 1990. Predatory behavior of grizzly bears feeding on elk calves in Yellowstone National Park, 1986-88. Int. Conf. Bear Res. and Manage. 8: 335-341.

Griffel D. E. and Basile J. V. 1981. Identifying sheep killed by bears. US Dep. Agric. Forest Serv. Res. Note INT-313.

Haglund B. 1968. Winter habits of the large carnivores II. Viltrevy 5:213-361. [In Swedish with English summary]

Murie A. 1948. Cattle on grizzly bear range. J. Wildl. Manage 12: 57-72.

Mysterud I. 1973. Behaviour of the brown bear (Ursus arctos) at moose kills. Norw. J. Zool. 21: 267-272.

Mysterud I. 1975. Sheep killing and feeding behaviour of the brown bear (Ursus arctos) in Trysil, south Norway 1973. Norw. J. Zool. 23: 243-260.

Mysterud I. 1980. Bear management and sheep husbandry in Norway, with a discussion of predatory behavior significant for evaluation of livestock losses. Int. Conf. Bear Res. and Manage. 3: 233-241.

Notario R. 1970. El oso pardo en España. Min. de Agric., Madrid: 1-162.

Purroy F. J., Clevenger A. P., Costa L. and Sáenz de Buruaga M. 1988. Demography of large mammals (wild boar, roe deer, red deer, wolf, and brown bear) in the Riano National Hunting Reserve: an analysis of their predation on livestock. Biol. Ambient. 1: 375-387. [In Spanish with English summary]

Rivas-Martínez S., Díaz T., Prieto J., Loidi J. and Penas A. 1984. Los Picos de Europa: la vegetacion de la alta montaña Cantábrica. Ediciones Leonesas, León: 1-255.

Semenov-Tian-Shanskii O. 1972. The brown bear in the Lapland Reserve, U.S.S.R. Aquilo Ser. Zool. 13: 98-102. 
Servheen C. 1989. The status and conservation of the bears of the world. Int. Conf. Bear Res. and Manage., Monogr. Ser. No. 2: 1-65.

Sokal R. R. and Rohlf F. J. 1981. Biometry. W. H. Freeman and Co., San Francisco, CA: 1-859.

Sorensen O. J. 1990. The brown bear in Europe in the mid 1980's. Aquilo Ser. Zool. 27: 3-16.

Received 29 December 1993, accepted 18 June 1994. 